\title{
Perspectives on Islamic Law, Justice and Society
}

\author{
R.S. Khare, ed.
}

Lanham, MD: Roman and Littlefield Publishers, Inc., 1999. 207 pages.

This short, 207 page book is a refreshing overview of Islamic legal principles and new trends within Islamic societies. Though Islamic law has often been viewed as a sluggish monolith, it is actually a rather dynamic field. R.S. Khare has assembled a number of distinguished academics to discuss Islamic law, not as a homogenous entity, but rather in light of the reality: that Islamic law is multi-faceted, varied, highly regional and must be viewed in light of historical changes.

Thus, this collection of essays focuses upon the manner in which Islamic law, as an organic law, is constantly reconciling historically changing socio-economic conditions with modernity and technology. The collection is organized in three parts. The first part outlines the concept of Islamic law, formal legal institutions and traditional Islamic scholarship. The second portion of the book focuses on the regionalism of Islamic law and the manner in which the colonial period had a provocative impact upon the evolution and endurance of certain Islamic legal institutions. The final portion of the collection uses two interesting cases in which modernity and technology are problematizing and calling for a fundamental rethinking of seemingly "basic" principles.

The unifying theme of the essays is the manner in which Islamic societies today are dealing with modernity and the manner in which technological advancements and global changes affect Islamic societies and concepts within Islamic law. Though at times the collection seems fragmented due to the different disciplines of the authors, this variety allows for a solid and nuanced understanding of the issues. 
The first essay, "The Ideal and Real in Islamic Law," by Abdulaziz Sachedina, offers a solid introduction to the Muslim perspective of Shari 'ah, from tracing the means by which it was derived to explaining the complexities of public law in Islam, and the epistemological crisis in Muslim societies that must reconcile the manner in which the nation-state system has divided laws into categories of "secular" and "religious." Concerned less with the substance of Islamic law, Sachedina focuses more upon the methodology behind the formation of Islamic law; a process that was bound to an ideal of Medinan society but was also profoundly influenced by practical concerns.

While Sachedina concentrates upon the relationship between human beings and God, anthropologist Lawrence Rosen focuses upon the interhuman connections that form Islamic law in his essay "Justice in Islamic Culture and Law." Rosen seeks to make the logic of Arab/Islamic legal systems digestible to western audiences, by rooting the logic in the context of the societies from which laws and norms arise. He argues that the concept of intentionality in Arab societies is different from that of western societies due to the context of bargained-for relationships that are central to the definition of the person in Arab culture. Though Rosen's approach to Islamic societies is clearly from a position that seeks to bridge a cultural divide, I believe he insists on a far greater divide than actually exists. The "contexts of human relationships" that Rosen emphasizes as a means to understand the eastern perspective is also central to Anglo-American laws.

John Simmons' essay, grounded in western legal philosophy, serves as a thoughtful critique of Rosen's argument. In "Fault, Objectivity, and Classical Islamic Justice," Simmons focuses upon Rosen's founding assumptions, commenting on the differences and similarities between Islamic and Anglo-American moral/legal theories. While Rosen contends that Islamic societies (and therefore Islamic law) see fault and responsibility as primarily objective, Simmons believes that, much like the Anglo-American tradition, Islamic law views fault by objective and subjective standards.

The second portion of the book, with its focus on Islamic law as a historical phenomenon, explores the effect of the colonial period on Islamic law in India and Algeria. Michael Anderson's well-researched article, "Legal Scholarship and the Politics of Islam in British India," explores the manner in which colonization affected Islamic legal thought, eventually relegating Islamic law primarily to the realm of personal status issues. $\mathrm{He}$ provocatively asserts that "colonial administrators may never have changed Islamic legal arrangements quite so profoundly as when they were trying to 
preserve them." According to Anderson, Anglo-Mohammadan scholarship focused more upon securing indigenous elite allegiance to the Crown than on a true understanding of Islamic tenets. Thus, the nuances and various forms of logic inherent in South Asian Islamic law as well as the diversity of Islamic schools of thought were obscured by a western paradigm of legal logic.

Updating Anderson's account to modern India, Tahir Mahmood explores the manner in which Islamic laws have interacted with Indian pubic laws. Freedom of religion, though formally assured, faces several legal and social problems. Mahmood bases his argument on the principle that basic Islamic values agree with the basic philosophy of Indian public law, both being grounded in humanist values. However, since the Indian Constitution needs to serve both Hindu and Muslim religio-moral values, tensions inevitably arise between the freedom of Muslims to practice their faith in a primarily Hindu state. Unfortunately, Mahmood fails to mention egregious and more dramatic tensions within Indian society that reflect vibrant anti-Muslim tensions, such as the destruction of the Barbri mosque by a mob of angry rioters and the failure of the secular state's police force to protect Muslim interests.

In "Changing Conceptions of Marriage in Algerian Personal Status Law," Bettina Dennerlein explores the effect of French colonization on Islamic legal systems and the resultant tension between Islamic and postcolonial secular laws. Basing her work upon a historical study of legal changes between 1963 and 1990, Dennerlein focuses upon family law. She asserts that developments in Algerian personal status laws are best analyzed in light of the "social field" of family law because it reflects society's basic social structure. In Algerian society one can see how Islamic law, customary law and colonial reforms/secular state law vie for primacy to reflect the values of the people. All reflect different segments of Algerian national identity.

The final portion of the book seeks to address new trends in the discourse of Islamic law. In "Woman, Half the Man? Crisis of Male Epistemology in Islamic Jurisprudence," Abdulaziz Sachedina tackles a problem that has been plaguing both Muslim and non-Muslim feminists: Muslim women's evidentiary testimony. The fact that the testimony of two women equals that of one man seems diametrically opposed to Islam's basic tenets of equality among the sexes. But his article asks a broader question than the technicalities of testimony: Is it possible for a male-dominated religious epistemology to provide an authentic interpretative voice for the female "other?" When male jurists rule on issues concerning both women and 
inter-gender relationships, they make gross assumptions as to the subjective female experience. Sachedina postulates that as a result, the present epistemological crisis in Islamic jurisprudence stems from the absence of female voices in Islamic legal discourse.

Sachedina's article is premised upon the notion that "whereas the Godhuman relations have remained more or less immutable in Shari>a, the area of inter-human relationships has demanded rethinking and reinterpretation of the normative sources like the Qur'an and Sunnah to deduce new directives under changed social conditions." Sachedina's essay serves as both a genealogy of Muslim jurists' attitudes towards gender and an activist call to Muslim women to be participants in the legal-ethical deliberations of jurists, so as to better redefine their status in modern societies. However, Sachedina fails to address the basic cultural and religious issues that keep women from being active participants in the male-dominated ulama.

The final essay, "Languages of Change in Islamic Law: Redefining Death in Modernity," by Ebrahim Moosa, explores the intersection of modernity with Islamic juridical semiotics through analysis of the legal opinion of the Academy of Islamic Jurisprudence (AIJ), a transnational organization which functions under the auspices of the Organization of Islamic Conference (OIC). In this essay, we see themes which have been examined throughout this collection come together.

Moosa investigates the historical evolution of Islamic approaches to brain death by taking into account the manner in which colonial rule, the displacement of traditional Muslim education, and technology have shaped the Shari>a's approach to the permissible and the impermissible. Moosa posits that this broad dichotomy of extremes - permissible and not permissible - is in itself faulted. Those open to change, view such changes as permissible on the basis of social necessity or public benefit, whereas traditionalists argue that the consequences of these changes go against the implicit or literal meaning of a religio-juridical text. Moosa employs the example of brainstem death (when a person has suffered irreparable brain injuries and his/her body is artificially ventilated) as a paradigm for this epistemological crisis in the face of changing medical technologies that call into question seemingly basic findings of dead or alive.

According to Moosa, the underlying tension arises because "[Islamic] legal theory is largely pre-modern in its epistemological and ontological coordinates." Today, most Muslim jurists still employ a pre-modern legal framework. As a result, when challenged by novel ethical problems, modern Muslim legal opinions lack coherence and consistency. 
R.S. Khare's collection of essays is thought-provoking and well organized as well as containing a diversity of viewpoints. One need not be an expert in Islamic law to understand the essays. Perspectives on Islamic Law, Justice, and Society provides remarkable depth and insight into the theological, historical, sociological and cultural aspects of Islamic law as the historically changing interpretation of a set of divine principles.

Yousra Y. Fazili

American University Washington College of Law

Washington, DC 